\title{
7 \\ global governance as sector-specific management
}

\author{
jim whitman
}

\section{introduction}

As globalization has developed from being an emergent phenomenon to a pervasive condition, the global qualities of human relatedness have become inescapable and of routine importance. Increasingly, in matters as varied as human health, environmental quality and economic stability, national and even local concerns must take into active consideration world-encircling lines of causation. So when we attach the qualifier 'global' to an issue such as human health, it is on an understanding that global health is not merely a statistical abstraction, but a specific form of complex interrelatedness with a range of serious implications, not least in the form of epidemics and pandemics. To the extent that various actors - public and private, national and international, alone and in combination - seek to monitor and improve human health and to cure or prevent diseases worldwide, we can say that their combined activities amount to the global governance of health ${ }^{1}$ (sometimes expressed as global health governance). This and related forms of global governance dedicated to specific arenas of activity or relations can best be termed sectoral. The other principal use of the term 'global governance' is summative - that is, global governance regarded as the totality of all governances, including but not limited to states and the international system.

Sectoral and summative global governance are meaningful abstractions rather than independent forms or levels of the regulation of human affairs. After all, the global governance of any form of human activity, or arena in which it takes place, depends upon a vast array of 
other orders, some quite distant from the sector under consideration. For this reason, the governances of what might fairly be said to comprise the infrastructure of globalization - air and sea transport, communications and finance - are only possible because of a summative global governance that enables myriad activities of such scale and complexity with a high degree of reliability. At the same time, the intensively globalized world we have created for ourselves is founded on but also requires global governance that cannot be merely local, spontaneous and additive - hence the analysis devoted to states and international organizations in devising, negotiating and maintaining the most prominent (and arguably the most important) forms of sectoral global governance. One might say that summative global governance and sectoral global governance are mutually constitutive, an understanding of which is captured in James Rosenau's characterization of 'governance without government' in which he sought to clear an analytical space for governance as a summative phenomenon related to, but not encompassed by, the governance activities of states:

'[G]overnance without government' does not require the exclusion of national and sub-national governments from the analysis, [but] does necessitate inquiry that presumes the absence of some overarching governmental authority at the international level. Put differently, the concept of 'governance without government' is especially conducive to the study of world politics inasmuch as centralized authority is conspicuously absent from this domain of human affairs even though it is equally obvious that a modicum of order, of routinized arrangements, is normally present in the conduct of global life. ${ }^{2}$

Of course, quite extensive 'routinized arrangements' create planetarylevel environmental crises, which require the most concerted forms of sectoral global governance negotiations (on climate change most notably); and so too do less crisis-driven concerns, such as world trade. From these two broad meanings of global governance - summative and sectoral - spring the many theoretical understandings and characterizations which comprise the largest part of the now extensive literature on the subject, including considerations of authority, legitimacy, agency and coordination.

There is a certain reassurance in the term 'global governance' and in the fact of regulatory oversight of activities that are generally taken to fall within any of its sector-specific forms. For example, the number 
and variety of organizations and mechanisms by which global finance is regulated are not only extensive but also command impressive resources - legal, political and capital. The governance of global finance also has a well-developed literature. ${ }^{3}$ Of course, provisions for the regulation of global finance and its many sub-systems are considerably more than a matter of minor adjustments to a stable and equitable status quo. As with every other area over which we can say that global governance is exercised, political contention, the pursuit of national and/or private interests and systemic uncertainties are a large part of its raison d'être - as the regular reports of the World Bank, IMF and WTO as well as academic critiques of those organizations make plain. ${ }^{4}$ And as with so many other forms of sectoral global governance, globalizing dynamics not only facilitate it but they also necessitate and/or exacerbate the conditions or issues it must contend with.

No form of sectoral global governance is proof against systemic shocks that is, actions, events or configurations of circumstance which undermine the capacity of a governance regime to function adequately, or which challenge its fundamental assumptions. Indeed, crises can stand as important tests of the reach, inclusivesness and responsiveness of regulatory systems in highly dynamic, globalized circumstances. Certainly systemic disruption in global finance is nothing new - notable recent examples include the stock market collapse of 1987; the1994 Mexican Peso crisis; the Asian financial crisis of 1997; and the bail out of the hedge fund Long-Term Capital Management in 1998. ${ }^{5}$ In order for the governance of global finance to have meaning, there must be a degree of preparedness and a demonstrable ability to cope with unforeseen events, unconsidered but pertinent dynamics or large-scale turbulence and in each of the foregoing cases, order and stability were resumed after various kinds of intervention. But from a sectoral global governance perspective, what are we to make of global financial turmoil as it began in 2007 and unfolded throughout 2008? Certainly, the crisis is of a span and severity that frustrates both measurement and prediction. In April 2008, the International Monetary Fund (IMF) predicted losses on US loans and securitized assets at 945 billion US dollars; in September, this was revised upward to 1.3 trillion dollars; and a month later, to 1.4 trillion. ${ }^{6}$ By the end of the year, the World Bank's Global Economic Prospects 2009 summarized:

The United States government introduced a $\$ 700$ billion rescue package and has taken equity positions in nine major banks and several 
large regional banks.... At the same time, European governments have announced plans for equity purchases of bank assets worth some $\$ 460$ billion, along with almost $\$ 2$ trillion in guarantees of bank debt.... Virtually no country, developing or high-income, has escaped the impact of the widening crisis. ${ }^{7}$

Similarly, the IMF's year-end World Economic Outlook described the turmoil as 'the largest financial shock since the Great Depression':

The subprime crisis that unfolded in 2007 has now morphed into a credit crisis that has caused major disruption to financial institutions in the United States and Europe. Intensifying solvency concerns about a number of the largest U.S.-based and European financial institutions have pushed the global financial system to the brink of systemic meltdown. ${ }^{8}$

Even without a reliable indicator of how much worse the situation might become, the looming possibility of a 'systemic meltdown' obliges us to ask hard questions about global governance and about this most extensive and politically supported form of sectoral global governance in particular. Certainly, there was no hiatus in governance initiatives or suspension of the activities of national and international institutions for this purpose. Indeed, as developments threaten to spiral out of control, we are more rather than less dependent on the institutions and mechanisms that were in place in the years before the current crisis. But it is also abundantly clear that the governance of global finance has been reduced to crisis management.

Yet perhaps the most compelling feature of the crisis is its extent. This is most succinctly expressed in the depiction of its impacts on the world beyond the esoteric particulars of derivatives, futures and credit default swaps - what quickly came to be referred to as the 'real economy'. On proposing an initiative by EU governments to combat the economic effects of global financial turbulence via a stimulus package of 200 billion euros, European Commission President Jose Manuel Barroso asserted that 'Exceptional times call for exceptional measures. The jobs and well-being of our citizens are at stake. Europe needs to extend to the real economy its unprecedented coordination over financial markets. ${ }^{9}$ Wherever one might have chosen to draw the sector boundaries of global finance, the meaning of 'systemic meltdown' soon came to be understood as a system of systems - that is, one not confined to 
the familiar substance of global finance such as international banking and currency exchange, but one that included a severe downturn in the housing and commercial real estate markets in several countries; rapidly escalating unemployment which carries with it a range of secondary impacts; rising public sector borrowing requirements, exacerbated emergency provisions and declining tax revenues; and large losses on investment portfolios affecting pension funds and a wide range of public and private institutions. The shock waves also quickly reached the developing world as Robert Zoellick, President of the World Bank Group made plain: 'In July [2008] at the G8 summit, I said that developing countries were facing a double jeopardy from the impact of high food and fuel prices. But what was then a double jeopardy is now a triple hit - food, fuel, and finance - threatening not just to knock the poorest people down, but to hold them down. ${ }^{10}$

In these circumstances, it becomes difficult to maintain a clear separation between the sector-specific governance of global finance and the wider, summative global governance of which it is not only a key element, but with which it is also highly interactive. Once the unravelling of global finance had widened and gained pace, even historically unprecedented remedial action appeared to fall far short of the intended effect. US Treasury Secretary Henry M. Paulson's 700 billion dollar bailout of Wall Street was 'focused on buttressing U.S. financial institutions. But it was global markets that plunged [immediately afterwards] as investors sold off commodities in Brazil, currency in Mexico, bank stocks in Russia and the short-term debt of the state of California'. ${ }^{11}$ One could argue that what was required was more effective, or perhaps more truly global governance initiatives, as expressed by the reaction of a currency trader in response to the Paulson bail out: 'Quite frankly, what the market is looking for is some kind of coordinated action from central banks around the world. [The Paulson plan is like a] Band-Aid for a problem that stretches way beyond the banking system now ${ }^{12}$ - and way beyond the wealthiest nations and peoples, too, as Robert Zoellick acknowledged:

The events of September [2008] could be a tipping point for many developing countries. A drop in exports, as well as capital inflow, will trigger a fall off in investments. Deceleration of growth and deteriorating financing conditions, combined with monetary tightening, will trigger business failures and possibly banking emergencies. Some countries will slip toward balance of payments crises. As is always the case, the most poor are the most defenseless. ${ }^{13}$ 
It would appear that that metaphor beloved of advocates of economic globalization - that a 'rising tide lifts all boats', also applies in reverse.

Even allowing for the centrality of global finance to so many other systems, and for the severity of the crisis, the threat of a global financial meltdown was less the outcome of a 'perfect storm' than the dissolution of unsustainable positions and the practices that established them - all made possible either directly by governance initiatives (such as deregulation), by default ${ }^{14}$ and/or by developments which outpaced our systems of governance. ${ }^{15}$ As we struggle to contain the effects of the crisis and to find a rectificatory course that balances urgency against various social and political pressures, we might best reflect on the kinds of sector-specific global governance on which we rely to a considerable degree to ensure the fundamentals of stability and sustainability under globalized conditions.

\section{sectoral global governance: thematic considerations}

In outline terms, it is not difficult to identify a span of activities, relations or conditions which comprise a sphere of sectoral governance, either active or prospective. This is a practical necessity as well as an analytical convenience, since the effects of human activity are so profuse, wide-ranging and complex that they render impossible a single global governance which is both comprehensive and coherent. Globalizing dynamics ensure that the additive and cumulative consequences of human activity are felt ever more widely and quickly, and these prompt focused global governance undertakings not only in anticipatory modes (as in preparations for an avian flu pandemic), but also in ways that are both reactive and urgent, which certainly applies to our efforts to halt climate change.

Although we can register failure and inadequacy in our governance arrangements, 'success' is a more problematic concept because the business of governance is not the solution of problems but the adjustment of human ends and means to changing conditions. The essential aim of all forms of governance is the avoidance of severe and prolonged instability, as described by Geoffrey Vickers:

I shall describe as unstable any state of affairs in which the nature and rate of change makes regulation impossible and thus defeats the creation of any order. I shall also include as unstable that state of 
affairs in which any order generates its own negation so quickly that none of them can effectively be realized. I shall further include as unstable those orders which are realized only at the cost of leaving the physical, the institutional or the cultural environment unfit to support a worthy successor. None of these definitions is precise, but they include all the states which ... would be generally recognized as unstable today. ${ }^{16}$

By the end of 2008, the failure of the governance of global finance had become the epicentre of wider and more generalized instability; climate change was the most serious and urgent of a range of environmental threats to ecosystem integrity; and the effects of an avian flu pandemic would be disastrous. The consequences of failed or failing sectoral global governances on this scale might (and should) concentrate minds, but it neither concentrates nor simplifies the conduct of governance, for the thematic reasons outlined below.

\section{porous boundaries}

Our world is messy, dynamic and complex - and in the twenty-first century it is all of these things on a global scale. Any form of sectoral global governance is neater in respect of what it manages for than in respect of the number and kinds of variables it must manage. Globalization has configured the world so that local or individual concerns cannot entirely be sheltered from global dynamics; and at the same time, large-scale and/or inclusive global issues can be created or exacerbated by the cumulative and sometimes synergistic outcomes of small-scale activities. What this means for the practical purposes of exercising governance is not only that a failing in sectoral global governance can have extensive, multiple impacts (as we have seen in the case of global finance), but also that a great many actors and dynamics that have a bearing on sector-specific governance originate outside of its purview - yet these need to be regulated and/or coordinated for the purpose of achieving systemic stability. For example, the calculation of emissions limits for atmospheric pollutants must eventually find expression across a span of human enterprises and activities that include mining, electricity generation, agriculture and transport; and it will impact national economic development and output as well as individual opportunities and choices.

The 'seamlessness' of our globalized world ensures that most forms of sectoral governance will need to be highly adaptable (the global 
governance of health cannot prevent the mutation of pathogens); to undertake monitoring in the absence of effective 'reach' (the World Health Organization's GOARN system ${ }^{17}$ is a case in point); to frame goals that do not require oversight of every pertinent variable; and to accept that in some cases, the avoidance of the worst outcomes will not only be a sine qua non, but also the lowest common denominator amongst what have come to be known as 'stakeholders'. ${ }^{18}$

Indeed, the effects of sectoral global governances will by no means be limited to willed outcomes, much as, more generally, the attainment of larger goals usually entails unforeseen and/or unacknowledged risks and costs. ${ }^{19}$ In addition, distinct sectoral governances also impact on each other in ways that have often proved highly contentious, such as between trade and environmental protection.

\section{no hierarchy of governances}

The arena of sectoral global governance is, like the arena of international relations, anarchic. There is no overarching global governance, and the aims of any one sectoral global governance are not conceived for, and do not aspire to, a larger, common global governance goal, or even to necessarily compatible outcomes. This is because there are no sectoral governances detached from sectoral interests - and these are frequently of a much narrower and self-interested cast than the claims of human security or planetary sustainability. The governance goals determined for any sector of activity (such as trade) or condition (such as the physical environment) need to be internally self-consistent, but there is no 'global' requirement that they do not conflict across sectors. However, there is some hope that although our sectoral governances are unlikely to become seamless, they could at least be made more congruent with each other. ${ }^{20}$

Although there are no hierarchies of governance per se, there are hierarchies of power. These find expression in the ends as well as the means of governance. In the following critique of governance and development, 'good governance' criteria (means) are linked to larger neo-liberal governance ends, via the Bretton Woods institutions and the interests of powerful states:

A discussion over governance becomes important as it influences not only mechanisms but also strategies, each of which in turn responds to ideological presumptions about development and the means to attain greater economic democracy. Unfortunately the overly eager 
leadership of the World Bank in framing the good governance debate, as with the UNDP and World Bank partnership to implement the Millennium Development Goals, tends to narrow the possibilities for a critical examination of the World Bank's role in creating poverty and malgovernance through their structural adjustment programs and 'state modernization' schemes. Questioning the global trade and finance regime, and global political malgovernance, is clearly outside the hegemonic discussion parameters - to avoid approaching malgovernance, hunger and extreme poverty as political issues, preferring instead to leave them in the hands of highly-paid 'technical' experts. $^{21}$

One need not adopt the position that sectoral global governances in sum comprise a hegemonic project ${ }^{22}$ to discern that the powerful will use the means at their disposal, including the mechanisms of governance, to secure their interests. At the same time, governance arrangements that can truly said to be global will inevitably entail negotiation and compromise rather than imposition, since power is highly differentiated across sectors, and because systemic stability and the maintenance of a broadly favourable status quo is a key interest for the powerful. World trade is a cooperative endeavour, sustained by kinds and degrees of interdependence which require extensive and intricate governance arrangements; and although this governance is shaped by the needs and interests of the powerful, their own needs enmesh them in complex relationships that cannot be supplanted by the exercise of power alone.

\section{there is no escape from politics}

It is certainly the case that 'Governance theorists see the role of government in governance as a contextual phenomenon; the pursuit of the collective interest takes different forms in different political and institutional contexts and governments can be either the key, coordinating actor or simply one of several powerful players in the process. ${ }^{23}$ However, large-scale, global governance arrangements will almost certainly entail the participation of states, either directly or in the form of international organizations or regimes. The 'governance without government' phenomenon notwithstanding, the scale of the challenges presented by global issues generally require the mobilization of resources and the legitimacy and authority to enact or enforce agreements that only states possess. (Acting on their own, no coalition of NGOs and/or 
transnational corporations could wield the kinds of practical means as well as the necessary political and legal authority that states can bring to bear on an issue like climate change.) This point does not diminish the importance of non-state and private actors in framing or sustaining governance arrangements, ${ }^{24}$ and nor does it make political dynamics the preserve of states. But while it is clear that states and the international system have well-established and practiced means for addressing issues that encompass their common interests, the strength of those interests can also militate against the creation and functioning of even the most pressing regulatory arrangements. This can be particularly acute when related national goods are likely to be negatively impacted as the price of an agreement, or when negotiating positions are constrained by the weight of the expectation of citizens whose interests may well be more individual, local and immediate. Both of these have inhibited climate change negotiations.

Of course, the 'horse trading' that routinely attends multilateral negotiations also applied in the case of the Kyoto protocol. After the United States pulled out of its obligations in 2001, Russia was the only state with the ability to ensure that the total greenhouse gas emissions of signators would meet the treaty-mandated 55 per cent - and this it used to its advantage, to lever its admission to the WTO. "We are for the Kyoto process," [Russian President] Putin said during a news conference after a summit with European leaders. "We support it, although we do have some concerns over the obligations that we will have to assume. The European Union has met us halfway in negotiations on the WTO, and it could not help but have a positive effect on our attitude toward ratification of the Kyoto protocol".'25

Still more fundamental are the interests of powerful states in establishing and adjusting sectoral governance for relative and/or competitive advantage. In other words, weaker states can be locked into uncompetitive and more seriously disadvantaged positions, which, in the case below, may impart systemic stability to world trade, but at the price of making its 'global' character considerably less inclusive and equitable than the term might suggest:

[T]he role of the developing countries in the WTO negotiations has undergone a significant change. Earlier, they had been negotiating mostly for special concessions and relaxations from the developed countries, whereas now the negotiations are more about extracting concessions from them.... [T] he developed countries have started 
taking up these negotiations with a new determination to expand the access of their economic entities in developing countries. Their attitude and approach appear to have changed in recent years. The old concept of enlightened self-interest in seeing the harmony of their own long-term prospects with the development of developing countries has been replaced by expectations of immediate gains from expansion of current opportunities in the developing countries, irrespective of its effect on the economies of these countries. ${ }^{26}$

As an activity, global governance is not an objective exercise founded on scientific or technical expertise; and there is nothing inherent in any global governance arrangement that obviates the 'of by and for whom' question (discussed in Chapter 9.)

\section{The complexity and speed of global dynamics; and the slow pace of governance reckoning}

The notion that we could deplete the fish stocks of the world's oceans, damage the ozone layer or by our combined actions come to the brink of catastrophic climate change would once have been thought risible. But the extent of complex interactions of human and natural systems are not confined to crises; and from a governance perspective, what is most notable about these and other threats to global order is that they were unanticipated and entirely unwilled, largely driven by increasing human numbers and by widening and accelerating industrialization and consumerism. The result of this has been that some of our most important global governance initiatives have been undertaken to stabilize or reverse the outcome of activities that have been damaging and/ or destabilizing, but which were by no means ungoverned, in either sectoral or summative terms. This points not only to the practical and political difficulties of coordination on a global scale, but also to problems of forecasting - and indeed, problems of timely comprehension of global dynamics characterized by their complexity and speed.

Many of the benefits of globalization are based on the speed with which information, goods and services can be produced and/or made available, for which various summative forms of governance are sufficient. Hence the general reliability of international air travel, banking and trade, all of which rely on numerous and varied sub-systems to maintain them. But global connectedness extends far beyond our formal means of long-distance communication: ripple effects from quite disparate and scattered forms of activity also circulate around the world, 
sometimes with pernicious effect, as we have seen with the 'toxic debts' that originated in the sub-prime US housing market. These had been packaged into collateralized debt obligations (CDOs) which have now engulfed some of the world's largest banks and other financial institutions, with a scale of asset write-downs that were so difficult to estimate (or risky to reveal) that banking confidence was further undermined, thus exacerbating the credit squeeze and impacting economic performance more generally. Presently, the volume of foreign exchange exceeds three trillion dollars a day - and this is but one aspect of financial flows that are beginning to run beyond the kinds of comprehension necessary for ensuring systemic stability. But it is precisely those forms of deliberation that one experienced trader had in mind when he compared what he termed the 'old psyche' with the operation of the money markets in 2006:

[The 'old psyche' meant that] when somebody said to 'take a few weeks' to execute a trade, you didn't have to be attuned to the market all the time. Now, you have to be on top of it all the time and there's so much more to watch.... Money used to flow via bank loans, which is an insignificant game now. If there has been a real major change it's that hedge funds have taken over the role of global financing, Where banks were methodical and slow, hedge funds are fast. Hedge funds don't get themselves invested with clients by doing weeks of credit work, committee meetings, cross-selling and so on. For them, it's just a question of in or out, then a push of the button. ${ }^{27}$

The additive risk-taking by banks and other financial institutions, as we now know, was of systemic proportions or, through high-speed interconnectedness between systems, it had systemic implications. Whatever the future of financial regulation within and between states, it is open to question whether the kinds of complexity and speed which both underpin and result from globalizing processes can be subjected to the kinds of deliberation that any full understanding of 'governance' implies. ${ }^{28}$

Global dynamics which present us with unanticipated and/or unwanted consequences of the complex interaction of human and natural systems have lately come to be recognized as an integral and probably inescapable feature of globalization. With cheap international air travel comes the facilitated spread of infectious diseases; ${ }^{29}$ mundane, carbon-emitting behaviours such as car driving now have planetary 
implications (reflected in the 'carbon footprint' concept applied to individuals no less than to nations); and global warming has a secondary impact, thawing arctic tundra releases methane, which further debilitates the ozone layer. ${ }^{30}$

In an intensely globalized world, the room for 'disregarded externalities' is quickly disappearing; but by the same token, our ability to conceive and implement adequate systems of governance even on a sectoral level is coming under strain, particularly if one regards 'adequate' as including a comprehensive understanding of causal pathways and the capacity to collect and analyze data in a timely fashion. At the global level, further difficulties include insufficient or inconclusive data; inadequate conceptual grasp of systems and systems behaviour; scientific uncertainty; and the problem of prediction under sensitive-dependent conditions (the so-called butterfly effect) - the capacity of small, initial factors to affect outcomes in non-linear natural and human systems.

Although in general we can assign more or less weight to each of the four thematic particulars above, in practice, they are often configured together, in ways which can present formidable challenges to summative as well as sectoral forms of global governance. Climate change, for example, traverses all four: there can be few significant forms of sectoral governance that will be able to shelter from its direct and indirect effects; there is no prioritization of governances such as would secure the future of the planet more urgent than it has been to date; our attempts to address it are intensely political; and as the consequences of changing climate begin to be felt more immediately and sharply, few will doubt the importance of the complex interaction of human and natural systems. All of these considerations can seem quite distant from a developed world perspective, from which the benefits of globalization and the kinds of governance it both requires and supports appear generally effective and broadly beneficent. But tensions, inequities and unsustainable practices are part of our governance arrangements no less than in other forms of social and political organization, and they become visible on an examination of any form of sectoral global governance, two of which are briefly considered below.

\section{sectoral global governance in practice: human health and food}

The global governance of health is well established and extensive and includes the World Health Organization (WHO), national health 
authorities, regional bodies, specialist establishments (such as the US Centers for Disease Control and the Pasteur Institute), international organizations with remits concerned with or related to health (such as UNDP) and a vibrant epistemic community linking epidemiologists, medical practitioners and vaccine researchers. ${ }^{31}$ There are some advantages to the global governance of health as a network rather than as a formal structure, but national, political, cultural and other divides dictated the form, rather than considerations of effectiveness.

The global governance of food is more diffuse, and the network of governance systems is much more closely attuned to powerful sectoral interests. The remits of the UN World Food Program (WFP) and the Food and Agriculture Organization (FAO) are less extensive than their titles suggest; and national political considerations keep them constrained in the scope of their non-emergency operations. Yet there are also numerous sub-sector governances covering aspects of agriculture and agricultural trade, food security, food safety and nutrition, to list but a few. This work is strengthened and sometimes critiqued by private, voluntary and humanitarian organizations in both developmental and emergency modes.

For both the health and food sectors, there are separate but related enterprises which have a practical bearing on them but which largely operate 'across' rather than from within the generally acknowledged boundaries of both. In the case of food, for example, the governance of trade has a powerful, sometimes determining effect on nations' food security, their balance of payments, import and export needs and the availability and nature of employment. Agriculture that is geared to export entails questions of ownership of land, access to water, use of pesticides and fertilizers, and in some cases, the introduction of genetically modified crops - all of which have extensive, secondary effects beyond the immediate compass of food needs and production. ${ }^{32}$ In the case of health, nearly all of the world's larger systems of governance have strong and often multiple impacts on individual and community health, beginning with our halting efforts to address climate change. ${ }^{33}$ To this, one can add the mortality and morbidity statistics that parallel inequalities of every kind between the developed and developing worlds. War and other forms of political violence and their aftermaths further add to this burden. ${ }^{34}$

In short, although both food and health can be meaningfully abstracted as arenas for dedicated attention and practical governance initiatives, the sources of much of what is amiss in both are located in 
other arenas, shaped by different (if not altogether conflicting) interests and subject to their own forms of governance. For example, in the following, a WTO technical note describes the provisions of the TradeRelated Aspects of Intellectual Property Rights (the TRIPS Agreement) as a tensioned balance between what are deemed 'short-term interests' that is, access to cheaply produced pharmaceuticals by people in the developing world - and the need to provide 'incentives' for continuing research and development:

Finding a balance in the protection of intellectual property between the short-term interests in maximizing access and the long-term interests in promoting creativity and innovation is not always easy. Doing so at the international level is even more difficult than at the national level. Perhaps nowhere do these issues excite stronger feelings than in regard to pharmaceutical patents, where tension between the need to provide incentives for research and development into new drugs and the need to make existing drugs as available as possible can be acute. ${ }^{35}$

On the matter of the availability of food, even in 2008, the United Nations Human Rights Council was unable to achieve a unanimous vote in favour of there being a human right to food - a logical necessity in view of the long-accepted human right to life. ${ }^{36}$

The boundaries of sectoral governances are not all permeable to the same degree; and those which have human security as either an explicit goal or an implicit remit - such as food and health - are most likely to be impinged upon by others. This is due in no small measure to the porosity of all sectoral governances and because of the number of variables that need to be secured in order for all human beings to enjoy adequate nutrition and at least basic standards of health care. Of course, hard interests, both material and political, also feature. Also, global governance of food or of health considered as a dedication to global inclusion would, in addition to unprecedented degrees of political consensus, require regulatory coherence that does not exist in any other area of governance. As a consequence of these factors, both food and health as sectoral global governances are themselves functionally 'sectorized' - that is, the arenas are global but the governances are confined to place-specific and/or subject specific initiatives which are at their most effective when the practical and political interests of powerful constituencies are engaged (as in the prevention of an avian flu pandemic), or when costs to them 
are sited within manageable bounds. Any inclusive and equitable global governance of food could hardly coexist with the level of agricultural subsidies currently in place in the developed world; instead, we have the sum of many sub-sectoral governances of food, neither entirely consistent nor necessarily global in compass or outlook. More striking is that the indirect effects of pressures from within other sectoral governances can push the governance of food and health further away from regulatory and normative matters towards emergency provision. So as governments slash their aid budgets in the wake of financial turmoil, the WFP revealed that it would be hard pressed to provide food for 49 million people in the world's worst hunger-stricken countries. Yet '... one per cent of the money being used to fund financial bail-outs in Europe and the US could entirely fund the WFP's operations'. ${ }^{37}$

Explicit political considerations not only determine the lager contours of sectoral global governance but they can also drive instrumental uses (or abuses) of governance systems. ${ }^{38}$ And political responses also arise in response to quite specific occurrences or grievances, even when they can obstruct the attainment of much larger governance goals:

Indonesia sent a chill through the World Health Organization recently when it refused to supply any more samples of the avian flu virus that has killed scores of its people. The move, which seemed aimed at gaining access to vaccines at an affordable price, threatens the global effort to track the virus and develop vaccines. But Indonesia has raised a valid point that needs to be addressed: if a pandemic should strike, poor countries would be left without protection.... The WHO relies on a global network of laboratories to provide virus samples so experts can determine which are most likely to spread.... Indonesia decided to act after a foreign company announced work on a vaccine that would be based on its samples. Indonesia stopped cooperating with the WHO and started negotiations to send future samples to another vaccine maker in return for technology that would allow Indonesia to make its own vaccine. That may be good for Indonesia but could be harmful to global health - especially if other countries follow. Clearly Indonesia, which is in discussion with WHO officials, needs to rejoin the global network. Unfortunately, the organization has no good answer to the inequities Indonesia has spotlighted. ${ }^{39}$

The global governance of food is rooted in the complex interaction of human and natural systems through agriculture; and as agriculture 
extends to transnational agribusiness and world trade, food becomes enmeshed in these dynamics on a global scale. The most recent global food crisis of 2008 is particularly wide-ranging in the number of its pertinent contributing elements and quite dramatic in its effects and implications. However, it can also be read as indicative of the difficulties confronting the global governance of any sector of activity. According to $\mathrm{FAO}$, the factors that led to the crisis (which has given rise to food riots and some countries banning the export of rice) included 'weatherrelated production shortfalls; reduction of stock levels; increasing fuel costs; the surge in demand for biofuels and agricultural commodities; the changing structure of demand; operations of the financial markets; and short-term policy actions and exchange rate swings' ${ }^{40}$ Added to this, food aid declined to a 50-year low even before the worst of the 2008 financial turbulence manifested itself. ${ }^{41}$ At the same time, the speed and responsiveness of another set of human systems ensured that there were winners as well as losers: the emergency food summit in Rome in June 2006 failed to reach an agreement to ensure that demand for biofuel crops did not worsen the food shortages, but 'corn prices rose on the world markets throughout the last hours of the summit'. ${ }^{42}$

Within the arena of global health, local human susceptibility to pathogens is now greatly amplified by the ease and speed of global travel, which is how HIV/AIDS quickly became a pandemic. Our many failings and inconsistencies in meeting the challenges of this pandemic mean that it has now become a global dynamic itself, ${ }^{43}$ undermining the balances of and between human and natural systems, within Africa most strikingly, but also beyond its shores. More broadly, indices of human health are a particularly sensitive measure of the interchange between global dynamics and local contingencies and of what Paul Farmer has termed 'the biological consequences of social inequalities'. ${ }^{44}$

\section{conclusion}

None of the foregoing diminishes the importance of sectoral global governance; and it is important to bear in mind what can be accomplished given sufficient interest or incentive. The outbreak of SARS and the international response which so quickly halted it was far from perfect in all its particulars, but remains an impressive example of the marshalling of health governance actors and mechanisms and the swift use of other well-governed scientific, political and social resources. What is perhaps more impressive was the elimination of smallpox in the 1970s, 
driven by those least susceptible to the disease; and currently, there is no shortage of goodwill and concerted efforts are devoted to eliminating a number of other diseases, several of them most severe in, or particular to, the developing world. ${ }^{45}$ But the global governance of health and of food persists alongside more than 800 million malnourished people. Some aspects of both forms of governance struggle against this and other injustices (or are obliged to mitigate their consequences); but other aspects are contributory factors.

There are clearly serious disjunctions in our organizations of political community. We are capable of creating and maintaining intricate and complex forms of sectoral and intersectoral governance sufficient to maintain the routine functioning of bewilderingly fast and complex human systems, yet find ourselves unable to find a modicum of political consensus necessary to ensure planetary sustainability, let alone human security for those currently disenfranchised. There are innumerable inefficiencies and dysfunctions within sectoral governances, but as the fundamentals of the human condition are increasingly shaped by global dynamics of many kinds, these functional matters are less immediately important than the 'global' quality of the oversight we bring to our various forms of governance - and to their coordination. It appears to be the case that the least global aspect of our globalized world is the governance systems in place to regulate and stabilize it. Nor is it difficult to discern sectoral interests (particularly at state level) which have been sharpened by globalizing processes and secured by governance mechanisms at the expense of any truly global governance. So while there is no doubting the importance of the performance of sectoral global governances for purposes and constituencies of varying inclusiveness, true global governance remains a daunting task - all the more because we are very unlikely to be able to undertake it at a leisurely pace.

\section{notes}

1. Keley Lee (ed.), Health Impacts of Globalization: Towards Global Governance (Basingstoke: Palgrave, 2002); Andrew F. Cooper, John J. Kirton and Ted Schrecker (eds), Governing Global Health: Challenge, Response, Innovation (Aldershot: Ashgate, 2007).

2. James N. Rosenau, 'Governance, Order and Change in World Politics,' in James N. Rosenau and Ernst-Otto Czempiel (eds), Governance Without Government: Order and Change in World Politics (Cambridge: Cambridge University Press, 1992), p. 7. 
3. Horst Siebert (ed.), Global Governance: An Architecture for the World Economy (New York: Springer, 2003); Kern Alexander, Rahul Dhumale and John Eatwell, Global Governance of Financial Systems: The International Regulation of Systemic Risk (Oxford: Oxford University Press, 2005); Rodney Bruce Hall, Central Banking as Global Governance: Constructing Financial Credibility (Cambridge: Cambridge University Press, 2008).

4. Robert O'Brien, Anne Marie Goetz, Jan Aart Scholte and Marc Williams, Contesting Global Governance: Multilateral Economic Institutions and Global Social Movements (Cambridge: Cambridge University Press, 2000).

5. For a brief chronology of international monetary, securities and banking crises, see John Braithwaite and Peter Drahos, Global Business Regulation (Cambridge: Cambridge University Press, 2000), table 8.2, p. 135.

6. 'IMF predicts $\$ 1.4$ trillion in losses from crisis,' International Herald Tribune, 7 October 2008.

7. World Bank, Global Economic Prospects 2009, available at http://web. worldbank.org/WBSITE/EXTERNAL/EXTDEC/EXTDECPROSPECTS/ GEPEXT/EXTGEP2009/0,,contentMDK:21959964 pagePK:64167702 piPK: 64167676 theSitePK:5530498,00.html

8. International Monetary Fund, 'World Economic Outlook: Financial Stress, Downturns, and Recoveries,' October 2008, available at http://www.imf. org/external/pubs/ft/weo/2008/02/index.htm

9. 'EC pushes $\$ 256$ Billion in spending to battle crunch,' 26 November 2008. Available at http://www.700billiondollarbailoutplan.com/category/eu-economy/

10. The World Bank, News and Broadcast, available at http://web.worldbank. org/WBSITE/EXTERNAL/NEWS/0,,contentMDK:21933764 menuPK:51416187 pagePK:64257043 piPK:437376 theSitePK:4607,00.html

11. David Cho and Binyamin Appelbaum, 'Unfolding Worldwide Turmoil Could Reverse Years of Prosperity,' Washington Post, 7 October 2008, page A01.

12. Ibid.

13. Robert B. Zoellick, 'Modernizing Multilateralism and Markets,' Prepared remarks at the Peterson Institute for International Economics, 6 October 2008, available at http://www.petersoninstitute.org/publications/papers/ paper.cfm?ResearchID=1012

14. Edmund L. Andrews, 'Greenspan Concedes Error on Regulation,' New York Times, 24 October 2008.

15. One analyst commented 'If this is the death of Wall Street as we know it, the tombstone will read: killed by complexity.' Nils Pratley, 'The day the ticking time bombs went off,' The Guardian, Tuesday 16 September 2008, in which he quotes the investor Warren Buffett, writing a decade before the crisis: 'The derivatives genie is now well out of the bottle, and these instruments will almost certainly multiply in variety and number until some event makes their toxicity clear. Central banks and governments have so far found no effective way to control, or even monitor, the risks posed by these contracts.'

16. Geoffrey Vickers, Freedom in a Rocking Boat: Changing Values in an Unstable Society (London: Allen Lane/Penguin, 1970), p. 127. Italics original.

17. The World Health Organization's Global Outbreak Alert and response network, available at http://www.who.int/csr/outbreaknetwork/en/ 
18. Mikael Wigell, 'Multi-Stakeholder Cooperation in Global Governance,' The Finnish Institute of International Affairs, June 2008.

19. See Bent Flyvbjerg, Nils Bruzelius and Werner Rothengatter, Megaprojects and Risk: An Anatomy of Ambition (Cambridge: Cambridge University Press, 2003).

20. Margaret Lay, 'Can Trade Policy Support the Next Global Climate Agreement? Analyzing the International Trade and Environment Regimes,' Carnegie Papers, Number 96, September 2008; Aseem Prakash and Matthew Potoski, 'Racing to the Bottom? Trade, Environmental Governance, and ISO 14001,' American Journal of Political Science, Vol. 50, No. 2, April 2006, pp. 350-364.

21. Alejandro Bendaña, "Good Governance" and the MDGs: Contradictory or Complementary?' paper presented at the IGNIS-Conference 'Whose Governance? Obstacles to the MDGs' at Mastemyr (Oslo) 20-21 September 2004, available at http://www.rorg.no/Artikler/740.html

22. Jörg Friedrichs, 'Global Governance as the Hegemonic Project of Transatlantic Civil Society,' in Markus Lederer and Philipp S. Müller (eds), Criticizing Global Governance (Basingstoke: Palgrave, 2005), pp. 45-68; Mark Duffield, Global Governance and the New Wars: The Merging of Development and Security (London: Zed Books, 2001).

23. Jon Pierre, 'Conclusions: Governance beyond State Strength,' in Jon Pierre (ed.), Debating Governance (Oxford: Oxford University Press, 2000), p. 241.

24. Rodney Bruce Hall and Thomas J. Biersteker (eds), The Emergence of Private Authority in Global Governance (Cambridge: Cambridge University Press, 2002; see also Braithwaite and Drahos, Global Business Regulation.

25. Peter Baker, 'Russia Backs Kyoto to Get on Path to Join WTO,' Washington Post, 22 May 2004, available at http://www.washingtonpost.com/wp-dyn/ articles/A46416-2004May21.html

26. Bhagirath Lal Das, 'Strengthening Developing Countries in the WTO,' Third World Network (Trade and Development Series No. 8), available at http://www.twnside.org.sg/title/td8.htm

27. Interview with Yra Harris, Chicago Mercantile Exchange, in Steven Dronby, Inside the House of Money: Top Hedge Fund Traders on Profiting in the Global Markets (Hoboken: Joseph Wiley \& Sons, 2006), p. 204.

28. See Jim Whitman, The Limits of Global Governance (Abingdon: Routledge, 2005).

29. David P. Fidler, SARS, Governance and the Globalization of Disease (Basingstoke: Palgrave, 2004).

30. 'Siberia feels the heat: a frozen peat bog the size of France and Germany combined, contains billions of tonnes of greenhouse gas and, for the first time since the ice age, it is melting,' Ian Sample, 'Warming hits "tipping point",' The Guardian, 11 August 2005.

31. For a list of global health authorities and organizations, see http://www. pda.org/MainMenuCategory/QualityRegulatoryAffairs/LinkstoGlobal HealthAuthoritiesandOrganizations.aspx

32. For an introduction to the range of social, political, health and environmental factors involved in the global governance of food, see Peter Oosterveer, Global Governance of Food Production and Consumption: Issues and Challenges (Cheltenham: Edward Elgar Publishing Ltd, 2007); and Raj Patel, Stuffed and 
Starved: From the Farm to the Fork, the Hidden Battle for the World Food System (London: Portobello Books, 2007).

33. World Health Organization, Report by the Secretariat, 'Climate Change and Health,' EXECUTIVE BOARD EB122/4, 122nd Session 16 January 2008, available at http://www.who.int/gb/ebwha/pdf_files/EB122/B122_4-en. pdf; UK Department of Health, Health Effects of Climate Change (2001/02), available at http://www.dh.gov.uk/en/Publicationsandstatistics/ Publications/PublicationsPolicyAnd Guidance/DH_4007935

34. E.G. Krug, L.L. Dahlberg, J.A. Mercy, A.B. Zwi and R. Lozano, (eds), World Report on Violence and Health (Geneva: World Health Organization, 2002), available at http://www.who.int/violence_injury_prevention/violence/ world_report/en/

35. World Trade Organization, 'Pharmaceutical patents and the TRIPS Agreement,' 21 September 2006, available at http://www.wto.org/english/ tratop_e/TRIPS_e/pharma_ato186_e.htm

36. UN General Assembly, GA/SHC/3941 (Sixty-third General Assembly, Third Committee), 'Third Committee draft text endorses recommendations, future workplan of Human Rights Council's working group on right to development,' available at http://www.un.org/News/Press/docs/2008/ gashc3941.doc.htm

37. Peter Beaumont, 'UN aid agencies facing hunger funding crisis,' The Guardian, 17 December 2008.

38. Peter Wallensteen, 'Scarce Goods as Political Weapons: The Case of Food,' Journal of Peace Research, Vol. 13, No. 4 (1976), pp. 277-298; Robert L. Paarlberg, 'Food as an Instrument of Foreign Policy,' Proceedings of the Academy of Political Science, Vol. 34, No. 3 (1982), pp. 25-39.

39. International Herald Tribune (Opinion), 'Indonesia's avian flu holdout,' 16 February 2007.

40. UN Food and Agriculture Organization, 'Soaring Food Prices: Facts, Perspectives, Impacts and Actions Required,' April 2008, p. 4, available at http://www.fao.org/fileadmin/user_upload/foodclimate/HLCdocs/HLC08inf-1-E.pdf

41. Javier Blas, 'Food aid declines to near 50-year low,' Financial Times, 9 June 2008, available at http://www.ft.com/cms/s/0/06e5b31a-3645-11dd-8bb80000779fd2ac.html

42. Julian Borger, 'Food summit fails to agree on biofuels,' The Guardian, 6 June 2008; see also Geoffrey Lean, 'Multinationals make billions in profit out of growing global food crisis,' The Independent, 4 May 2008.

43. Robert L. Ostergard, Jr, HIV/AIDS and the Threat to National and International Security (Basingstoke: Palgrave, 2007); Nana K. Poku, Alan Whiteside and Bjorg Sandkjaer (eds), AIDS and Governance (Aldershot: Ashgate, 2007).

44. Paul Farmer, Infections and Inequalities: The Modern Plagues (Berkeley: University of California Press, 1999). See also Laurie Garrett, Betrayal of Trust: The Collapse of Global Public Health (Oxford: Oxford University Press, 2001).

45. See the New York Times 2006 series of articles, 'Disease on the Brink,' available at http://www.nytimes.com/ref/health/2006_BRINK_SERIES.html 